\title{
THE IMPORTANCE OF THE OCCUPATIONAL FACTORS IN LOCAL FOOD CONSUMPTION BEHAVIOR
}

\author{
Caner ÇALIŞKAN*, Çiğdem SABBAĞ ${ }^{* *} \&$ Bekir Bora DEDEOĞLU***
}

\begin{abstract}
In the context of tourism and regional development, local food consumption has become one of the popular research topics in recent years. Despite this importance, there are no studies specifically addressing the impact of the occupational factors on local food purchasing behavior, while the role of age, gender, education, income and belief in purchasing behaviors is among the demographic components of most of the researches. In this study, local food consumption behaviors of individuals from different occupations were investigated and results were evaluated from the perspectives of tourism, sustainability, regional identity and development. The research was conducted in Adıyaman province of Turkey, where the traditional production continues and the consumption of local food is widespread. As the results of the research, occupation have been influential on the local food purchasing behaviors of participants in the fields of housewifery, healthcare, agriculture and food. Moreover, the income also has been influential factor on the purchasing behavior of local food of selfemployed and workers.
\end{abstract}

Keywords: Tourism. Local Food. Occupation. Purchasing Behaviors. Adıyaman.

\section{A IMPORTÂNCIA DOS FATORES OCUPACIONAIS NO COMPORTAMENTO DE CONSUMO ALIMENTAR LOCAL}

o contexto do turismo e do desenvolvimento regional o consumo local de alimentos tornou-se um dos tópicos de pes mais populares nos últimos anos. Apesar desta importância não existem estudos que abordem especificamente o impacto dos fatores ocupacionais no comportamento local de compra de alimentos, enquanto o papel da idade, gênero, educação, renda e crença nos comportamentos de compra está entre os componentes demográficos da maioria das pesquisas. Neste estudo, os comportamentos locais de consumo alimentar de indivíduos de diferentes profissões foram investigados e os resultados foram avaliados a partir das perspectivas de turismo, sustentabilidade, identidade regional e desenvolvimento. A pesquisa foi realizada na província Adıyaman da Turquia, onde a produção tradicional continua e o consumo de alimentos locais é generalizado. Conforme os resultados da pesquisa, a ocupação tem influenciado os comportamentos locais de compra de alimentos dos participantes nas áreas de limpeza doméstica, saúde, agricultura e alimentação. Além disso, a renda também tem sido um fator influente no comportamento de compra de alimentos locais de trabalhadores autônomos e trabalhadores.

Palavras chave: Turismo. Comida Local. Profissão. Comportamentos de Compra. Adıyaman.

\section{LA IMPORTANCIA DE LOS FACTORES OCUPACIONALES EN EL COMPORTAMIENTO DEL CONSUMO LOCAL DE ALIMENTOS}

En el contexto del turismo y el desarrollo regional, el consumo local de alimentos se ha convertido en uno de los temas de investigación popular en los últimos años. A pesar de esta importancia, no hay estudios que aborden específicamente el impacto de los factores ocupacionales en el comportamiento local de compra de alimentos, mientras que el papel de la edad, el género, la educación, los ingresos y la creencia en los comportamientos de compra se encuentran entre los componentes demográficos de la mayoría de las investigaciones. En este estudio, se investigaron los comportamientos locales de consumo de alimentos de individuos de diferentes profesiones y se evaluaron los resultados desde las perspectivas del turismo, la sostenibilidad, la identidad regional y el desarrollo. La investigación se llevó a cabo en la provincia de Adiyaman, Turquía, donde continúa la producción tradicional y el consumo de alimentos locales es generalizado. Como resultado de la investigación, la ocupación ha sido influyente en los comportamientos locales de compra de alimentos de los participantes en los campos de la ama de casa, la salud, la agricultura y la alimentación. Además, los ingresos también han sido un factor influyente en el comportamiento de compra de los alimentos locales de los trabajadores por cuenta propia y los trabajadores.

Palabras clave: Turismo. Comida local. Profesión. Comportamientos de compra. Adiyaman.

\footnotetext{
${ }^{*}$ Ph.D. in Tourism Management (2015) at Nevsehir HBV University. He is assistant professor at the Department of Tourism Management at Adiyaman University. His research interests include tourism sociology, destination branding, tourist behavior, and organizational behavior. Adress: Adıyaman Üniversitesi (ADYÜ), Altınşehir Mah. 3005. Sk. No:13 02040, Merkez / Adıyaman, Turkey. [ccaliskan@adiyaman.edu.tr] Orcid ID: https://orcid.org/0000-0002-7774-1769 ${ }^{*}$ Ph.D. in Nutritional sciences (2009) at Ankara University. She is associate professor at the Department of Tourism Management at Adıyaman University. Her research interests include nutrition, healthy nutrition, gastronomy and local food culture. Adress: Adıyaman Üniversitesi (ADYÜ), Altınşehir Mah. 3005. Sk. No:13 02040, Merkez / Adıyaman, Turkey. [ csabbag@adiyaman.edu.tr ] Orcid ID: https://orcid.org/0000-0003-1538-9437.

${ }_{* \star *} \mathrm{Ph}$.D. in Tourism Management (2016) at Akdeniz University. He is associate professor at the Department of Tourism Guiding at Nevsehir HBV University. His research interests include tourism marketing, social media marketing, destination marketing, destination branding, tourist behavior, and hospitality marketing. Adress: 2000 Evler Mahallesi, Zübeyde Hanım Cd., 50300 Merkez/Nevşehir Merkez/Nevşehir, Turkey. [ b.bora.dedeoglu@nevsehir.edu.tr ] Orcid ID: https://orcid.org/0000-0002-0722-3392
} 


\section{INTRODUCTION}

Formation of an increasing awareness concerning the environment and health issues in last two decades aroused a deep curiosity in the consumers on the production techniques of the foods and the transparency of the food chain. In addition to this, while the re-occurrence of the small sized local farms and local food selling stores reveal the whole picture of the food production economy and policies, also became the partial solution tool of the environmental, social and economic concerns (Autio, Collins, Wahlen, \& Anttila, 2013). It is important that the local food consumption being the agenda of the popular media is a global conclusion of the "glocal" food act being conducted at the "global" level.

Numerous books, magazines, TV programs, and newspaper articles seem to give this trend a direction in particular. As a matter of fact, from the recent times to today, dozens of books on local dietary lists and human histories that have spent years on these diets continue to be on the shelves (Byker, Rose, \& Serrano, 2010).

On the other hand, it can be said that the increase in the tendency towards local food leads to the rediscovery of local production, natural life and local markets. Thus, it can be considered that local food has an important meaning in terms of tourism, sustainability, regional identity and development (Bessiere, 1998; Sati, 2019; Sims, 2009). According to Everett and Aitchison (2008), in the context of tourism, food is a functional tool in retention and development of regional identity and socio-culture, the enhancement of environmental awareness and sustainability.

The local food markets that attract attention of visitors from different cultures express the growing importance of local / cultural items on a global scale. Because local food is accepted as the image of a common identity for some regions, or even a sense of belonging to that region (Zepeda \& Deal, 2009).

Similarly, the examination of local foods and consumption habits is also important in terms of questioning the place of this term on the global market scale (Hall, Mitchell, Sharples, Mitchell, \& Sharples, 2004). At his point, it is known that variables such as marital status (Robinson \& Smith, 2002), age, socio-economics (Megicks, Memery, \& Angell, 2012) and education (Skuras et al., 2006) are used from time to time to better explain and interpret the relationship between consumer attitudes and consumption behaviours (Feldmann \& Hamm, 2015). In addition this, it is thought that occupation that is an another impartont factor in the formation of social relations and identity, as well provides individuals with knowledge and skills in specific areas (Karakuş, Onat, \& Yetiş, 2018; Sarıkaya \& Khorshid, 2009) will also have an impact on the local food purchasing behavior.

There are no studies specifically addressing the impact of the occupational factors on local food purchasing behavior. It is thought that; clarify the varied positive or negative factors (common reasons, effect of the media, hygiene problems etc) on local food purchasing behavior can provide valuable contribution to evaluate tourism, regional sustainability and identity.

\section{LITERATURE REVIEW}

Today, local food stores are now seen side by side with large-scale shopping malls. In addition to this, the diversification of the places where food is sold and the forms of presentation are changing the reasons of consumers' preferences. These factors include items such as quality, safety, health, honesty and sustainability (Gosling, Queiroz, Meints, \& Christino, 2017; Onozaka, Nurse, Choices, \& 2010, 2010).

On the other hand, consumers' reasons for choosing local foods can deepen according to different motivations and attitudes. While some consumers criticize the increasing amount of imports in the national food market, they tend to local food due to this reason. Through a hedonic approach, another group perceives local foods as fresher, safer and most importantly, healthier than imported products (Eren, Nebioğlu, \& Şık, 2017; Feldmann \& Hamm, 2015).

In a similar meaning, today a more efficient food system is formed in every respect by the local food fact. The idea that local food is fresher, believing in that it contributes to the regional economy and creating a fairer market by rejecting the hegemony of the conventional food system lead consumers to local food (Mariola, 2008). Larson and Story, (2009) claim that the main drivers in food consumption are individual, cultural, economic and social factors.

On the other hand, in the tendency to the local foods, the community considers flavour, tradition, health, safety, sustainable environment and local economy (Bianchi \& Mortimer, 2015; Morris \& Buller, 2003). Similarly, the most frequently observed attitudes in purchasing local foods are related to the freshness of the product, the health effect, the adaptation to the environment and the 
contribution to the local economy (Feldmann \& Hamm, 2015; Kumar \& Smith, 2018).

Along with the growing interest in the supply and demand side, it is discussed that there is no standard definition of local food in the relevant literature (Adams \& Salois, 2010). Although the concept of "local" is controversial (Edwards-Jones et al., 2008; Onozaka et al., 2010), it appears that there are numerous scientific researches on local food-consumer perceptions and consumption trends (Feldmann \& Hamm, 2015). While the notion that is commonly found in everyday language is mainly expressed as food produced and consumed in a specific place (Jones, Comfort, \& Hillier, 2004), the full meaning is again left to the perception of the consumers in general (Pearson et al., 2011).

Why, how and by whom local food is consumed is another important issue. According to Zepeda and Deal (2009), knowing the origin of the product and the relationship established with the producers are motivating factors for the people who are in the local food purchasing behaviour.

The factors that consumers commonly associate with local foods are quality, freshness, flavour, nutrition, health and trust, etc. In addition, the perceived quality of local foods is among the factors affecting the consumer's purchasing decision (Esteves \& Fernandes, 2016; Karakuş \& Çoban, 2018). Interestingly, some consumers may also load social meanings to their food consumption preferences by constantly interacting with producers (Aprile, Caputo, \& Nayga, 2016; Moraes \& Emmendoerfer, 2015; Zepeda \& Deal, 2009).

Skuras, Dimara, and Petrou, (2006) divide the consumers' local food purchasing decisions and spending behaviours into give factor groups as economic (income), demographic (age, gender, family size), social (education, origin) factors, as well as previous experiences and product knowledge.

De Irala-Estevez (2000) similarly stated that factors such as education, social class, poverty, income, gender and region were effective in food consumption and also mentioned the occupation variable. However, Girgin (2018) found that factors such as occupation, income and age have differentiating effects on local food consumption motivations.

In another study, Koç et al. (2012), it was seen that the rate of local food consumption varies according to occupations. As a result, occupational factors such as other socio-economic indicators and demographic variables are thought to be effective in local food consumption.

\section{METODOLOGY}

In this study, local food consumption behaviours of individuals from different occupations were investigated. The research was conducted in Adıyaman province located in a historic geography in the South East Anatolia region of Turkey. Adıyaman, where rural and urban life areas are close to each other and rural consumption habits are dominant, is one of the provinces where the traditional production continues and the consumption of local food is widespread.

The data sources of the research are composed of individuals from different occupations residing in the centre of the province. In addition to this, it has been noted that related individuals routinely have a habit of consuming local food. For this reason, a qualitative approach has been adopted in the method design and it has been reached to the participants with snowball sampling method (Biernacki \& Waldorf, 1981).

With this method, it was possible to establish a one-to-one dialogue with data sources and to analyse the participants' social experiences in detail (Atkinson \& Flint, 2001). A face-to-face interview technique, which provides a flexible data richness on the reached mass, was applied; so it was possible to gather in-depth information about participants' attitudes, behaviours and thoughts (Güven, 2006).

For the identification of the occupational groups, two criteria were taken into consideration as prevalence and interest. Accordingly, occupations have been collected under eight groups as; selfemployed, workers, civil servants, housewives, food I agriculture field, health, academicians and teachers. A total of 56 people as seven from each occupation group were interviewed.

On the other hand, during the data collection process, a semi-structured interview form was used, in which the main boundaries were evident, but the data gained depth with instant questions. The interviews lasted between 30 minutes to 2 hours were made by the researchers themselves and so data security was provided (Yüksel \& Yüksel, 2004).

The data obtained from interviews were analysed in two ways. In interviews with content analysis, the data obtained under predetermined themes were coded, and expressed in frequency and percentage (Yıldırım \& Şimşek, 2013). On the other hand, by means of descriptive analysis, the data have been appropriately expressed (Braun \& Clarke, 2006; Kümbetoğlu, 2008; Yıldırım \& Şimşek, 2013). 


\section{ANALYSIS AND DISCUSSION}

\subsection{Object of Study and its Context}

Because of local food and local food consumption has become one of the popular and important research topics in recent years, in this study, local food consumption behaviors of individuals were adressed. In this study, unlike other studies, local food consumption behaviors of individuals from different occupations were investigated. Results from the research were also evaluated from the perspectives of tourism, sustainability, regional identity and development.

\subsection{Data Description}

Table Findings obtained from the research were handled in two parts. In the first section, demographic data were available. In the second section, the findings obtained by content analysis and the opinions expressed by descriptive analysis method were included.

\section{Section I}

The demographic data belonging to 56 participants interviewed are provided in table 1.

Table 1. Demographic Data of Participants.

\begin{tabular}{|l|c|r|c|}
\hline Occupation & Avg. Income ( ) (Turkish Liras) & Number of Household & Dwell \\
\hline Self-Employment (SE) & $<2500$ & $\geq 4(\mathrm{n}=6)$ & $\geq 15(7)$ \\
\hline Worker (WRK) & $<2500$ & $\geq 4(\mathrm{n}=1)$ & $\geq 15(5)$ \\
\hline Civil servant (CS) & $2500-3500$ & $<4(\mathrm{n}=4)$ & $<15(2)$ \\
\hline Housewife (HW) & (Family Income) & $<4(\mathrm{n}=3)$ & $\geq 15(2)$ \\
\hline Healthcare (HC) & $3000-5000$ & $\geq 4(\mathrm{n}=4)$ & $<15(5)$ \\
\hline Agricultural/Food (A/F) & $3000-3500$ & $<4(n=1)$ & $\geq 15(7)$ \\
\hline Academician (AC) & $3000-5000$ & $\geq 4(\mathrm{n}=3)$ & $\geq 15(3)$ \\
\hline Teacher (TCH) & $4500-7500$ & $\geq 4(\mathrm{n}=4)$ & $<15(4)$ \\
\hline
\end{tabular}

Source: prepared by the authors.

The participants with the lowest income level belong to the self-employed and worker group

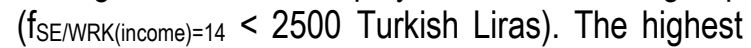
level of income has been seen in the academician occupation group ( $f_{A C \text { (income) }=7} 4500-7500$ Turkish Liras). It is seen that the number of family members of the participants was often 4 or more ( $f_{40 \text { (household) }}$ $\left.\geq 4 ; f_{16(\text { household) }}<4\right)$. In addition to this, the number of people who live in the province for 15 years or more is higher $\left(f_{33(d w e l l)} \geq 15 ; f_{23(d w e l l)}<15\right)$.

\section{Section II}

The data obtained by content analysis are given in Table 2. Table shows the distributions of responses of each occupation group within the total. Participants were asked about the problems experienced while purchasing local foods.

While the low quality was the most common problem in the group of self-employed $\left(f_{S E(l o w q u a l i t y)}=31 \% 27\right)$ and academicians ( $\left.f_{A C(\text { lowquality })=31 \% 27}\right)$, the staleness was a problem for the agriculture / food
$\left(f_{A F(S t a l e n e s s)}=5 \% 26 f_{A F(S t a l e n e s s)}=5 \% 26\right)$ group; and hygiene $\left(f_{H C}=6\right.$ (insanitarys)/55\%) was a major problem in the health group. On the other hand, the frequency of repetition of the phrase "I do not have a problem" in the housewife group ( $f_{H W(\text { not }}$ problem) $)=51 \% 31$ ) is remarkable. At this point, some participants in the local food procurement process used the following statements:

"Sometimes they mix stale products with fresh products to sell ..." (HCl).

"... There is often no quality standard in local foods, and therefore products are not very hygienic." (AC2).

While some participants do not experience any problem with local food, knowing the the place where they shop played an important role in this.

"We, my family, relatives and neighbours always shop from the same place. We are familiar with them... So we don't have problem" (HW4). 
Participants were asked about the reasons for purchasing local products, and health / naturality had similar significance in almost every occupation (eg, $\quad \mathrm{f}_{\mathrm{CS} \text { (healthy/naturality) }}=7 \% 1 \% ; \quad \mathrm{f}_{\mathrm{HW}}$ (healthy/naturality) $=61 \% 12$;

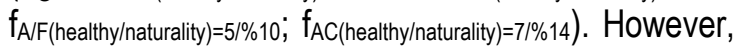
supporting the local producer had significance in the field of agriculture I food $\left(f_{A F(\text { support) })=6 / \% 46}\right)$. A participant from the agriculture / food occupation group stated the following on the subject:

"... Of course, local production is always important for me. So I also support the producer as well" (A/F7)

Participants were asked about the impact of the media on their local food purchasing behaviours and it was observed that the media played an important role in the purchasing behaviours of housewives $\left(f_{H W(\text { media) }}=71 \% 27\right)$.

"... The media is effective, of course. Particularly I pay attention to the explanations of specialist doctors who gets on television programs." (HW1).

Participants were asked what kind of local food they are purchasing. In almost every occupation group, the percentage of products purchased was close to each other (eg, $\mathrm{f}_{\mathrm{SE} \text { (vegetable) }=4 \% \% 16 \text {; }}$ $f_{C S}$ (vegetable)=4\%16; $\quad f_{A F(\text { vegetable) }=4 \% 1 \% \text { ) }} ; \quad f_{C S(\text { darires) }=5 / \% 13 ;}$; $f_{H C(\text { daries })=5 / \% 13} ; f_{A C(\text { dairies })=6 / \% 15)}$.

During the interviews, the safety of local foods was asked. While it was stated in each occupation group that the local foods are purchased from

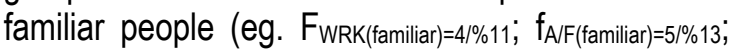
$f_{H W(f a m i l i a r)=5 \% 13}$ ), they also said that they confirm the safety of the foods in this manner.

"We are constantly purchasing from the same person ... Also, the explanation of the seller concerning the product and shopping of everyone from that producer satisfies me on reliability." (AC6)

"I am getting local food upon the recommendation of my friends and neighbours. I buy a little and try. I buy more if I like. " (CE3)

Participants were asked to where they complained about unsuitable products. While the agriculture / food occupation group complained mostly to the Alo 174 Food Line $\left.\left(f_{A F F(174 C a l l)}\right)=5 / 56 \%\right)$, the place of complain in each remaining group was usually the place where the product was purchased from (eg. $f_{H W(\text { salesperson) })=5 / 13 \%} ; f_{A C(\text { salesperson) })=6 / 17 \%}$ ).
During the interviews, the place where the local food was usually purchased was asked. It is quite interesting that only one participant used the supermarket expression (f $f_{\text {WRK(supermarket) }=1,100 \%}$ ). In addition to this, it is seen that the participants shop at the place, producer, local market or local bazaar where the local foods are sold (eg. $f_{A / F(\text { producerl) })=5 \% 112) \text {; }}$

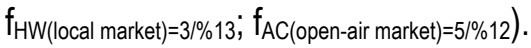

Finally, the most important issues considered during the purchasing of local foods were asked to the participants. Nutritive value ( $f_{H C}($ nutritive value) $\left.)=7 / 18 \%\right)$ was very important for the health occupation group, while the taste, appearance, the seller's behaviour, and safety were of equal importance to almost any occupation group. In addition to this, the price issue was most important for the self-employed

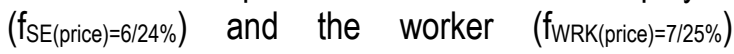
occupation group.

\subsection{Data Discussion}

Changing times and conditions are affecting consumers' food preferences. Nowadays, there is a serious demand for foods that are less processed, without additive, with low calorie and resistant to chronic diseases (Darian \& Tucci, 2011; Taşdan et al., 2014). In particular, the widespread of healthy living conscious has led to local food movement.

Nevertheless, the local food issue that became the health policy of many countries has become a global reality basing on individual, cultural, economic and social reasons (Lang, Stanton, \& Qu, 2014). This study is designed to better understand the motivations underlying local food consumption. Obviously, the local food consumption behaviours of people living in a region can provide an important insight into the local food marketing in tourism, sustainability of regional values and building/maintaining local identity.

According to Furst, Connors, Bisogni, Sobal, and Falk (1996), our food choice process incorporates not only decisions based on conscious reflection, but also those that are automatic, habitual and subconscious. In this context, the results can be explained as follows: housewives often do not have a problem when purchasing local foods. Adıyaman has an introverted society structure. At this point, while there is a strong communication network within the community (Çalışkan, 2015), the level of awareness of local stores is high especially among housewives. As a matter of fact, it was seen that most housewives do not experience problems because they shop from familiar and known people. 
Table 2. Distributions of Responses of Each Occupation Group Within the total.

\begin{tabular}{|c|c|c|c|c|c|c|c|c|c|c|c|c|c|c|c|c|c|}
\hline \multirow{2}{*}{$\begin{array}{l}\text { Expressions } \\
\text { Faced problems with local food products }\end{array}$} & \multicolumn{2}{|c|}{ Self-Employment } & \multicolumn{2}{|c|}{ Worker } & \multicolumn{2}{|c|}{ Civil Servant } & \multicolumn{2}{|c|}{ Housewife } & \multicolumn{2}{|c|}{ Healthcare } & \multicolumn{2}{|c|}{ Agricultural/Food } & \multicolumn{2}{|c|}{ Academician } & \multicolumn{2}{|c|}{ Teacher } & \multirow{2}{*}{$\begin{array}{c}\text { Total } \\
\mathrm{f}\end{array}$} \\
\hline & $f$ & $\%$ & $f$ & $\%$ & $f$ & $\%$ & $f$ & $\%$ & $f$ & $\%$ & $f$ & $\%$ & $f$ & $\%$ & $f$ & $\%$ & \\
\hline & 3 & 27 & 1 & 9 & 2 & 18 & - & 00 & - & 00 & 1 & 9 & 3 & 27 & 1 & 9 & 11 \\
\hline Staleness & 2 & 11 & 3 & 16 & 3 & 16 & 2 & 11 & 1 & 5 & 5 & 26 & 1 & 5 & 2 & 11 & 19 \\
\hline No Problem & 2 & 13 & 2 & 13 & 1 & 6 & 5 & 31 & 2 & 13 & 1 & 6 & - & 00 & 3 & 19 & 16 \\
\hline Not $100 \%$ natural / mixing other ingredients & - & 00 & 3 & 25 & 1 & 8 & - & 00 & 2 & 17 & 1 & 8 & 4 & 33 & 1 & 8 & 12 \\
\hline Insanitary & - & 00 & - & 00 & 1 & 9 & - & 00 & 6 & 55 & 1 & 9 & 3 & 27 & - & 00 & 11 \\
\hline \multicolumn{18}{|l|}{ Reasons for purchasing local food } \\
\hline Health / Naturalness & 6 & 12 & 6 & 12 & 7 & 14 & 7 & 14 & 6 & 12 & 5 & 10 & 7 & 14 & 7 & 14 & 51 \\
\hline Flavor & 4 & 27 & 2 & 13 & 1 & 7 & 1 & 7 & 3 & 20 & - & 00 & 2 & 13 & 2 & 13 & 15 \\
\hline Confidence & 1 & 25 & - & 00 & 1 & 25 & - & 00 & - & 00 & 1 & 25 & - & 00 & 1 & 25 & 4 \\
\hline Support for domestic production & - & 00 & 4 & 31 & 1 & 8 & - & 00 & - & 00 & 6 & 46 & 2 & 15 & - & 00 & 13 \\
\hline \multicolumn{18}{|l|}{ The effect of the media on buying behavior of local food } \\
\hline No & 4 & 13 & 5 & 17 & 5 & 17 & - & 00 & 2 & 7 & 5 & 17 & 7 & 23 & 2 & 7 & 30 \\
\hline Yes & 3 & 12 & 2 & 8 & 2 & 8 & 7 & 27 & 5 & 19 & 2 & 8 & - & 00 & 5 & 19 & 26 \\
\hline (Because ...) Discourses of experts/ awareness raising & (3) & 13 & $(-)$ & 00 & (2) & 9 & (7) & 30 & (5) & 22 & (1) & 4 & $(-)$ & 00 & (5) & 22 & (23) \\
\hline (Because ...) I see and care in the commercial / program etc. & $(-)$ & 00 & (2) & 33 & $(-)$ & 00 & (2) & 33 & $(-)$ & 00 & (2) & 33 & $(-)$ & 00 & $(-)$ & 00 & (6) \\
\hline \multicolumn{18}{|l|}{ Type of food purchased } \\
\hline Vegetables & 4 & 16 & 7 & 28 & 4 & 16 & 1 & 4 & 1 & 4 & 4 & 16 & - & 00 & 4 & 16 & 25 \\
\hline Fruit & 3 & 18 & 5 & 29 & 3 & 18 & 1 & 6 & - & 00 & 1 & 6 & 1 & 6 & 3 & 18 & 17 \\
\hline Dairy products & 4 & 10 & 3 & 8 & 5 & 13 & 6 & 15 & 5 & 13 & 3 & 8 & 6 & 15 & 7 & 18 & 39 \\
\hline Dry Foods & 4 & 12 & - & 00 & 4 & 12 & 6 & 18 & 4 & 12 & 2 & 6 & 6 & 18 & 7 & 21 & 33 \\
\hline \multicolumn{18}{|l|}{ How to make sure it's safe } \\
\hline Buy from acquaintances & 4 & 11 & 4 & 11 & 5 & 13 & 5 & 13 & 4 & 11 & 5 & 13 & 5 & 13 & 6 & 16 & 38 \\
\hline Buy from where it is produced & 2 & 33 & 1 & 17 & - & 00 & 1 & 17 & - & 00 & 1 & 17 & 1 & 17 & - & 00 & 6 \\
\hline I control (taste, look, etc.) & 3 & 17 & 2 & 11 & 1 & 6 & 2 & 11 & 2 & 11 & 2 & 11 & 3 & 17 & 3 & 17 & 18 \\
\hline \multicolumn{18}{|l|}{ Where are the unsuitable products being complained } \\
\hline I do not complain & 3 & 25 & 1 & 8 & 1 & 8 & 2 & 17 & 2 & 17 & 1 & 8 & - & 00 & 2 & 17 & 12 \\
\hline Where I bought the product & 4 & 11 & 4 & 11 & 5 & 14 & 5 & 14 & 4 & 11 & 3 & 8 & 6 & 17 & 5 & 14 & 36 \\
\hline Provincial / District Food, Agriculture and Livestock Directorate & - & 00 & 1 & 17 & 1 & 17 & - & 00 & 1 & 17 & - & 00 & 3 & 50 & - & 00 & 6 \\
\hline Alo 174 Food Line & - & 00 & 1 & 11 & - & 00 & - & 00 & 1 & 11 & 5 & 56 & 2 & 22 & - & 00 & 9 \\
\hline \multicolumn{18}{|l|}{ Where to buy local food } \\
\hline Only places selling local food & 4 & 19 & 1 & 5 & 5 & 24 & 2 & 10 & 4 & 19 & 1 & 5 & 2 & 10 & 2 & 10 & 21 \\
\hline From producer & 4 & 10 & 4 & 10 & 4 & 10 & 6 & 14 & 5 & 12 & 5 & 12 & 7 & 17 & 7 & 17 & 42 \\
\hline From the local market & 3 & 13 & 3 & 13 & 2 & 7 & 3 & 13 & 2 & 7 & 2 & 7 & 2 & 7 & 6 & 26 & 23 \\
\hline Supermarket & - & 00 & 1 & 100 & - & 00 & - & 00 & - & 00 & - & 00 & - & 00 & - & 00 & 1 \\
\hline Open-air market/district bazaar & 5 & 12 & 4 & 10 & 4 & 10 & 7 & 17 & 6 & 14 & 5 & 12 & 5 & 12 & 6 & 14 & 42 \\
\hline \multicolumn{18}{|l|}{ Top issues to consider when buying local food } \\
\hline Flavor & 7 & 17 & 4 & 10 & 5 & 12 & 7 & 17 & 4 & 10 & 6 & 14 & 5 & 12 & 4 & 10 & 42 \\
\hline View & 4 & 13 & 3 & 10 & 2 & 6 & 8 & 13 & 3 & 10 & 3 & 10 & 3 & 10 & 5 & 16 & 31 \\
\hline Nutritive value & 5 & 13 & 3 & 8 & 4 & 11 & 5 & 13 & 7 & 18 & 5 & 13 & 5 & 13 & 4 & 11 & 38 \\
\hline The way behavior of the seller & 3 & 13 & 5 & 21 & 3 & 13 & 3 & 13 & 1 & 4 & 2 & 8 & 4 & 17 & 3 & 13 & 24 \\
\hline Being secure food & 5 & 11 & 4 & 9 & 6 & 13 & 7 & 15 & 7 & 15 & 5 & 11 & 6 & 13 & 7 & 15 & 47 \\
\hline Price & 6 & 24 & 7 & 25 & 1 & 4 & 3 & 12 & 2 & 10 & 3 & 12 & - & 00 & 3 & 12 & 25 \\
\hline
\end{tabular}

Source: prepared by the authors. 
According to another conclusion about the subject, hygiene was the most common concern of health occupationals. Obviously, it is seen that it is inevitable that an employee working in the field of health pays importance to hygiene standards. Nevertheless, hygiene, packaging and safety have become privileged concerns in the research conducted on nurses who are an important group of health care (Baysan \& Fatma, 2009; Eren \& Şener, 2017). Similarly, trust and nourishment for the participants in this group have been the most important issues when purchasing local food.

While different reasons were effective on the participants during the local food purchasing process, the priority of the individuals working in the agriculture/food sector was to support the local producers. Depending on this result, in the regions such as Adıyaman where agricultural activities are intensive, it is seen that people who are experts in the field of agriculture, etc. seem to be an important source of support, information and input for local farmers' product range (Özçatalbaş, O; Sözer, 2002).

According to another result obtained from the interviews, the media has been very influential on the purchase of housewives' domestic food. While the housewives in Turkey form an important mass of the morning television programs, health comes in the top among the most discussed subjects in these programs (Etiler \& Zengin, 2015). Thus, the explanations of nutritionists and doctors who visit these programs have been influential on housewives as a consumer (Ergönül, 2013).

While most of the participants submit their complaints on the local products to the place of purchase, -as can be estimated- the individuals in agriculture/food occupation group apply to Alo 174 Food Line mostly. Two situations arise here. The first is that the participants want to deal directly with the responsible of the problem.

Koç, Altun, Güleç, and Baydaş, (2012) claim that the rate of complaints submitted to the government agencies are very low, while more than half of the people who frequently consume local foods report their complaint about the product directly to the seller. A second issue is that as a matter of fact, the level of awareness of Alo 174 Food Line have not been formed sufficiently (Gündüz, \& Aydoğan, 2015; Incedal Sonkaya, Balcı, \& Ayar, 2018).

It is seen that as a local food, most of the participants buy milk and dairy products. In similar studies, it has been determined that consumers prefer milk (Uğur, \& Budak, 2015) cheese, butter and honey (Kadanali \& Dağdemir, 2016) more as local foods. The places where the participants buy their local foods were only the shops selling local food, producers, local markets or neighbourhood markets.

On the other hand, only one participant in the total said that s/he bought products from the supermarket. In various studies conducted, it has been determined that consumers mostly buy traditional products from local markets, familiar people I relatives, producers (Taşdan et al., 2014), special places where local food products are sold or neighbourhood markets (Kadanali \& Dağdemir, 2016).

Obviously, it can be said that the confidence in products sold in supermarkets and containing natural and fresh phrases is beginning to decrease, and therefore consumers can be said to be more oriented towards local products.

Hence, in the Guide on the Regulation on Food Labelling and Notification of Consumers published by the Ministry of Food, Agriculture and Livestock, the use of misleading expressions such as fresh, 100\% natural, authentic and homemade on the labels of the products sold in supermarkets have been prohibited or restricted (Rebuplic of Turkey Ministry of Food, 2017).

It has been determined that participants often take care of their taste and safety when purchasing local foods. According to Autio et al. (2013), while the safe perception of products is an important element in the purchase of local foods, their tastes attract consumers as well. Another conclusion of subject is that participants in the self-employed and workers' group pay the most attention to price mostly.

Indeed, while the price of traditionally prepared food is the last thing observed (Demirbaş, Oktay, \& Tosun, 2006), the fact that the level of income of selfemployed and worker groups in Adiyaman is lower than the developed provinces can be shown as a reason of this. However, the demographic data also show that these two occupations have low income levels.

The results of the research show that the occupation is effective on local food consumption behavior. These results also provide information that there are different sensitivities in the same society in terms of local food consumption. Interestingly, education level, income level and interaction areas (such as media and TV) are important source of data about the consumption patterns of local people. These results also illustrate the role of the local people in the relationship between Tourism and local food.

According to Mak, Lumbers, Eves, \& Chang (2012), individual factors and motivations are the necessary parameters for understanding the phenomenon of tourism and food consumption. Demographic factors and demographic changes, such as occupation, education and income, can be effective in local food consumption, destination selection, and 
creating motivations that also affect these preferences cyclically (Kim, Eves, \& Scarles, 2009). In short, it is arguable that, determining the positive and negative aspects of local consumption of locals is also valid for tourism-based food consumption.

\section{CONCLUSIONS AND IMPLICATIONS}

On the focus of today's world of food consumption; it is seen that the increasing awareness on health, quality perception, encouraging local producers and supporting regional economies (Kadanali \& Dağdemir, 2016; Kumar \& Smith, 2018; Thilmany, Bond, \& Bond, 2008) come to the fore. For this reason, the local food issue takes on a structure that dominates the food consumption market (Engelseth, 2015).

It seems that local food consumption, due to the meaning it carries, subjects to different perspectives, interpretations and analyses. However, as mentioned, it is obvious that there are dozens of similar studies in

\section{REFERENCES}

Adams, D. C., \& Salois, M. J. (2010). Local versus organic: A turn in consumer preferences and willingness-topay. Renewable Agriculture and Food Systems, 25(04), 331-341. https://doi.org/10.1017/S1742170510000219

Aprile, M. C., Caputo, V., \& Nayga, R. M. (2016). Consumers' Preferences and Attitudes Toward Local Food Products. Journal of Food Products Marketing, 22(1), $19-42$. https://doi.org/10.1080/10454446.2014.949990

Atkinson, R., \& Flint, J. (2001). Accessing hidden and hardto-reach populations: Snowball research strategies. Social Research Update, 33(1).

Autio, M., Collins, R., Wahlen, S., \& Anttila, M. (2013). Consuming nostalgia? The appreciation of authenticity in local food production. International Journal of Consumer Studies, 37(5), 564-568. https://doi.org/10.1111/ijcs. 12029

Baysan, F., \& Fatma. (2009). Hemşirelerin gıda ürünleri ile ilgili sağlık risklerine karşı tutumları. Retrieved from http://acikerisim.selcuk.edu.tr:8080/xmlui/handle/1234 $56789 / 8385$

Bessiere, J. (1998). Local Development and Heritage: Traditional Food and Cuisine as Tourist Attractions in Rural Areas. Sociologia Ruralis, 38(1), 21-34. https://doi.org/10.1111/1467-9523.00061

Bianchi, C., \& Mortimer, G. (2015). Drivers of local food consumption: a comparative study. British Food Journal, 117(9), 2282-2299. https://doi.org/10.1108/BFJ-03-2015-0111

Biernacki, P., \& Waldorf, D. (1981). Snowball Sampling: Problems and Techniques of Chain Referral Sampling. Sociological Methods \& Research, 10(2), 141-163. the related literature and that these studies are moving in the same axis.

This study bases on the occupation factor that we think is an important variable in the local food purchasing behaviour. Because while occupational behaviours are shaped by the culture, history and social structure of a place (Robertson \& Fitzgerald, 2010), all people live with the need for occupational behaviour due to the common union of their anatomical features and physiological mechanisms (Wilcock, 1995).

Therefore, using the demographic factors particularly such as the occupation in the impact to the obtained results and the interpretation of these impacts seem to be more important rather than just presenting as a salt data. Briefly, the evaluation of occupational behaviour, which is based on principles, values and past experiences, on the basis of food consumption trend can provide important predictions in sales and marketing efforts.

https://doi.org/10.1177/004912418101000205

Braun, V., \& Clarke, V. (2006). Using thematic analysis in psychology. Qualitative Research in Psychology, 3(2), 77-101.

Byker, C., Rose, N., \& Serrano, E. (2010). The Benefits, Challenges, and Strategies of Adults Following a Local Food Diet. Journal of Agriculture, Food Systems, and Community Development, 1(1), 125137. https://doi.org/10.5304/jafscd.2010.011.013

Çalışkan, C. (2015). Turizm Potansiyeli Olan Bölgelerin Kalkınma Sürecinde Toplumsal kapasiteyi Güçlendirme Stratejileri: Adıyaman Örneği. Nevşehir Hacı Bektaş Veli Üniversitesi, Nevşehir.

Darian, J. C., \& Tucci, L. (2011). Perceived health benefits and food purchasing decisions. Journal of Consumer Marketing, 28(6), 421-428. https://doi.org/10.1108/07363761111165930.

De Irala-Estevez, J., Groth, M., Johansson, L., Oltersdorf, U., Prättälä, R., \& Martínez-González, M. A. (2000). A systematic review of socio-economic differences in food habits in Europe: consumption of fruit and vegetables. European journal of clinical nutrition, 54(9), 706.

Demirbaş, N; Oktay, D; Tosun, D. (2006). AB sürecindeki Türkiye'de gıda güvenliği açısından geleneksel gıdaların üretim ve pazarlanması. Harran Üniversitesi Ziraat Fakültesi Dergisi, 10(3-4), 47-55.

Edwards-Jones, G., Milà i Canals, L., Hounsome, N., Truninger, M., Koerber, G., Hounsome, B., ... Jones, D. L. (2008). Testing the assertion that "local food is best': the challenges of an evidence-based approach. Trends in Food Science \& Technology, 19(5), 265274. https://doi.org/10.1016/J.TIFS.2008.01.008

Engelseth, P. (2015). Customer-Responsive Supply of Local Foods. Journal of Operations and Supply Chain Management, 8(3), 111-119. 
Eren, R., Nebioğlu, O., \& Şık, A. (2017). Knowledge Levels on Food Safety of Employees Working in Hotel Enterprises' kitchen: The example of Alanya. Journal of Multidisciplinary Academic Tourism, 2(1), 47-64. https://doi.org/10.31822/jomat.350175

Eren, R., \& Şener, B. (2017). Barriers For Implementing of HACCP Food Safety System: The Case Of Alanya. Journal of Multidisciplinary Academic Tourism, 2(1), 99-124. https://doi.org/10.31822/jomat.363837

Ergönül, B. (2013). Consumer awareness and perception to food safety: A consumer analysis. Food Control, $32(2)$, 461-471. https://doi.org/10.1016/J.FOODCONT.2013.01.018

Esteves, E. T., \& Fernandes, P. O. (2016). Tourism Destination Factors Choice For Alto Trás-Os-Montes' Region (Portugal): A Multivariate Analysis. Anais Brasileiros de Estudos Turísticos - ABET, 6(2), 4048. Retrieved from http://ojs2.ufff.emnuvens.com.br/abet/article/view/312 $8 / 1117$

Etiler, N., \& Zengin, Ü. (2015). Televizyon kanallarındaki gündüz programlarında kadın sağlığı ve toplumsal cinsiyete bakışın değerlendirilmesi. Türkiye Halk Sağlığı Dergisi, 137. https://doi.org/10.20518/thsd.02616

Everett, S., \& Aitchison, C. (2008). The Role of Food Tourism in Sustaining Regional Identity: A Case Study of Cornwall, South West England. Journal of Sustainable Tourism, 16(2), 150-167. https://doi.org/10.2167/jost696.0

Feldmann, C., \& Hamm, U. (2015). Consumers' perceptions and preferences for local food: A review. Food Quality and Preference, 40, 152-164. https://doi.org/10.1016/J.FOODQUAL.2014.09.014

Furst, T., Connors, A., Bisogni, C. A., Sobal, J., \& Falk, L. W. (1996). Food Choice: A Conceptual M odel of the Process. Appetite, 26, 247-266. Retrieved from http://baileynorwood.com/rcfp/files/GoodSource3.pdf

Gosling, M. de S., Queiroz, D. C. de, Meints, L. de R., \& Christino, J. M. M. (2017). O Que Faz o Visitante do Inhotim Tão Satisfeito? Anais Brasileiros de Estudos Turísticos - ABET, 7(2), 82-99. Retrieved from http://ojs2.ufff.emnuvens.com.br/abet/article/view/316 $4 / 1145$

Gündüz, O; Aydoğan, C. (2015). Önlisans Öğrencilerinin Gıda Güvenliği Bilinç Düzeyleri Üzerine Bir Araşsırma. Akademik Yaklaşımlar Dergisi, 6(1), 34-44.

Güven, S. (2006). Toplum biliminde Araştırma Yöntemleri. Bursa: Ezgi Kitabevi.

Hall, C. M., Mitchell, R., Sharples, L., Mitchell, R., \& Sharples, L. (2004). Consuming places: the role of food, wine and tourism in regional development, 3771. https://doi.org/10.4324/9780080477862-10

İncedal Sonkaya, Z., Balcı, E., \& Ayar, A. (2018). University Students Food Literacy and Food Safety Knowledge, Attitudes and Behaviors "Example of Amasya University Sabuncuoğlu Şerefeddin Health Services Vocational School. Turkish Bulletin of Hygiene and Experimental Biology, 75(1), 53-64. https://doi.org/10.5505/TurkHijyen.2018.99710

Jones, P., Comfort, D., \& Hillier, D. (2004). A case study of local food and its routes to market in the UK. British Food Journal, 106(4), 328-335. https://doi.org/10.1108/00070700410529582

Kadanali, E., \& Dağdemir, V. (2016). Tüketicilerin Yöresel Gıda Ürünleri Satın Alma İstekliliği. Retrieved from http://ziraatdergi.gop.edu.tr/Makaleler/2086686678_916.pdf

Karakuş, Y., \& Çoban, S. (2018). Anais Brasileiros de Estudos Turisticos ABET. Anais Brasileiros de Estudos Turísticos - ABET, 8(2), 8-20. Retrieved from http://ojs2.ufjf.emnuvens.com.br/abet/article/view/320 7

Karakuş, Y., Onat, G., \& Ardıç Yetiş, Ş. (2018). Evaluation of the Expectations of Executives for the Competencies of the Cooks: The Case of Nevşehir Accommodation Enterprises. Journal of Tourism and Gastronomy Studies, 6(4), 299-321. https://doi.org/10.21325/jotags.2018.311

Kim, Y. G., Eves, A., \& Scarles, C. (2009). Building a model of local food consumption on trips and holidays: A grounded theory approach. International Journal of Hospitality Management, 28(3), 423-431. https://doi.org/10.1016/J.IJHM.2008.11.005

Koç, B., Altun, T., Güleç, H., \& Baydaş, A. (2012). Geleneksel Gıda Ürünleri Tüketim Pazarının Analizi: Van Ili Uygulaması. In tarimarsiv.com. Konya, Turkey: 10. Ulusal Tarım Ekonomisi Kongresi. Retrieved from http://www.tarimarsiv.com/wpcontent/uploads/2017/05/295-301.pdf

Kumar, A., \& Smith, S. (2018). Understanding Local Food Consumers: Theory of Planned Behavior and Segmentation Approach. Journal of Food Products Marketing, 24(2), 196-215. https://doi.org/10.1080/10454446.2017.1266553

Kümbetoğlu, B. (2008). Sosyolojide ve antropolojide niteliksel yöntem ve araştırma. İstanbul: Bağlam Yayıncılık.

Lang, M., Stanton, J., \& Qu, Y. (2014). Consumers' evolving definition and expectations for local foods. British Food Journal, 116(11), 1808-1820. https://doi.org/10.1108/BFJ-03-2014-0117

Larson, N., \& Story, M. (2009). A Review of Environmental Influences on Food Choices. Annals of Behavioral Medicine, 38(S1), 56-73. https://doi.org/10.1007/s12160-009-9120-9

Mak, A. H. N., Lumbers, M., Eves, A., \& Chang, R. C. Y. (2012). Factors influencing tourist food consumption. International Journal of Hospitality Management, 31(3), 928-936. https://doi.org/10.1016/J.IJHM.2011.10.012

Mariola, M. J. (2008). The local industrial complex? Questioning the link between local foods and energy use. Agriculture and Human Values, 25(2), 193-196. https://doi.org/10.1007/s10460-008-9115-3

Megicks, P., Memery, J., \& Angell, R. J. (2012). Understanding local food shopping: Unpacking the ethical dimension. Journal of Marketing Management, 28(3-4), 264-289. https://doi.org/10.1080/0267257X.2012.658838

Moraes, W. V. de, \& Emmendoerfer, M. L. (2015). Community Basedtourism and Social Inclusion: 
Tourist Itinerary Analysis Community Based Project Good Practices in Serra do Brigadeiro - Mg / Brazil. Anais Brasileiros de Estudos Turísticos - ABET, 5(3), 26-35. Retrieved from http://ojs2.ufff.emnuvens.com.br/abet/article/view/310 $1 / 1098$

Morris, C., \& Buller, H. (2003). The local food sector. British Food Journal, 105(8), 559-566. https://doi.org/10.1108/00070700310497318

Onozaka, Y., Nurse, G., Choices, D. M.-, \& 2010, U. (2010). Local food consumers: How motivations and perceptions translate to buying behavior. JSTOR, 25(1), 1-6. Retrieved from https://www.jstor.org/stable/pdf/choices.25.1.03.pdf

Özçatalbaş, O; Sözer, İ. K. (2002). Antalya Ilii Elmalı ve Korkuteli İlçelerinde Tarıma Girdi Sağlayan KuruluşlarınFaaliyetleri ve Yayım Açısından Değerlendirilmesi. Mediterranean Agricultural Sciences, 15(2), 89-100.

Pearson, D., Henryks, J., Trott, A., Jones, P., Parker, G., Dumaresq, D., \& Dyball, R. (2011). Local food: understanding consumer motivations in innovative retail formats. British Food Journal, 113(7), 886-899. https://doi.org/10.1108/00070701111148414

Rebuplic of Turkey Ministry of Food, A. and L. (2017). Türk Gıda Kodeksi Gıda Etiketleme ve Tüketicileri Bilgilendirme Yönetmeliği Hakkında Kılavuz. Retrieved from https://www.tarim.gov.tr/GKGM/Belgeler/Mevzuat/Tali mat/TGK_Gida_Etiketleme_Tuketici_Bilgilendirme_Y onetmelik_Kilavuzu.pdf

Robertson, L., \& Fitzgerald, R. (2010). The Conceptualisation of Residential Home Environments: Implications for Occupational Therapy. British Journal of Occupational Therapy, 73(4), 170-177. https://doi.org/10.4276/030802210X12706313443983

Sarıkaya, T; Khorshid, L. (2009). Üniversite öğrencilerinin meslek seçimini etkileyen etmenlerin incelenmesi: Üniversite öğrencilerinin meslek seçimi. Türk Eğitim Bilimleri Dergisi, 7(2), 393-423.

Sati, V . (2019). Potential and Forms of Sustainable Village Tourism in Mizoram, Northeast India. Journal of Multidisciplinary Academic Tourism , 4 (1) , 49-62 . https://doi.org/10.31822/jomat.527278
Sims, R. (2009). Food, place and authenticity: local food and the sustainable tourism experience. Journal of Sustainable Tourism, 17(3), 321-336. https://doi.org/10.1080/09669580802359293

Skuras, D., Dimara, E., \& Petrou, A. (2006). Rural tourism and visitors' expenditures for local food products. Regional Studies, 40(7), 769-779. https://doi.org/10.1080/00343400600660771

Taşdan, K., Albayrak, M., Gürer, B., Kongresi, O. Ö.-D., Sözlü, U., \& 2014, U. (2014). Geleneksel Gıdalarda Tüketicilerin Gıda Güvenliği Algısı: Ankara Ili Örneği. In yucita.org. Retrieved from http://yucita.org/uploads/yayinlar/diger/makale/Gelene ksel_Gdalarda_Tuketicilerin_Gda_Guvenlii_Algs.pdf

Thilmany, D., Bond, C. A., \& Bond, J. K. (2008). Going Local: Exploring Consumer Behavior and Motivations for Direct Food Purchases. American Journal of Agricultural Economics, 90(5), 1303-1309. https://doi.org/10.1111/j.1467-8276.2008.01221.x

Uğur, T; Budak, D. (2015). Risk communication in food products: case of milk in Adana. In researchgate.net (pp. 251-258). Konya, Turkey: 2nd ICSAE 2015, International Conference on Sustainable Agriculture and Environment. Retrieved from https://www.researchgate.net/profile/Muhammad_Imr an106/publication/307508778_COTTON_GROWERS 'SATISFACTION_WITH_PUBLIC_AND_PRIVATE EXTENSION_SERVICES_CASE_STUDY_OF_MUZ AFFARGARH_DISTRICT_OF_PAKISTAN/links/5aa7 bb1fa6fdcc9576d54df4/COTTON-GROWERSSATISFACTION

Wilcock, A. (1995). The occupational brain: A theory of human nature. Journal of Occupational Science, 2(2), 68-72. https://doi.org/10.1080/14427591.1995.9686397

Yıldıım, A., \& Şimşek, H. (2013). Sosyal bilimlerde nitel araştırma yöntemleri. Ankara, Turkey: Seçkin Yayıncillk.

Yüksel, A., \& Yüksel, F. (2004). Turizmde Bilimsel Araştırma Yöntemleri. Ankara: Turhan Kitabevi.

Zepeda, L., \& Deal, D. (2009). Organic and local food consumer behaviour: Alphabet Theory. International Journal of Consumer Studies, 33(6), 697-705. https://doi.org/10.1111/j.1470-6431.2009.00814.X. 